\title{
Using dried kitchen food wastes as untraditional feed in growing rabbit's diets
}

Farouk Imam Saad Helal ${ }^{1}$, Alaa Eldin Yehia El Badawi ${ }^{1}$, Mohamed Mohamed Basyony ${ }^{2}$, Eman El Sabaawy ${ }^{1}$ and Soad El Naggar ${ }^{1 *}$ (D)

\begin{abstract}
Background: Kitchen food wastes (KFW) are food lost from human especially from hotels, hospitals, cafeterias and home, could be alternative feed resources and create the attention of researchers to process these wastes and recycling it as animal feeding not only to reduce the use of expensive feed ingredients but also to decrease the environmental pollution. The main objective of this study was conducted to investigate the effect of dietary KFW inclusion on growth performance, digestibility, carcass traits, and some blood biochemical parameters of growing New Zealand White rabbits.

Results: The results showed that rabbits fed on diets containing 30\% KFW achieved significantly $(P<0.05)$ higher daily weight gain $(22.61 \mathrm{~g})$ than the control $(20.79 \mathrm{~g})$ and there were no difference between diets $10 \%$ and $20 \%$, and the lowest daily gain was with diet $40 \%$. The highest organic matter (OM) and crude protein (CP) digestibility were recorded in rabbits fed on a diet containing 30\% KFW (64.08 and 64.29\%, respectively), while the lowest was observed in $40 \%$ group (61.11 and 55.54\%, respectively). Diets containing KFW decreased caecal ammonia nitrogen $\left(\mathrm{NH}_{3}-\mathrm{N}\right)$ and increased propionate up to $30 \%$ substitution. The addition of KFW to rabbits diets had no significant effect $(P<0.05)$ on serum globulin, glucose, ALT, and AST values and increased significantly $(P<0.05)$ serum total protein, albumin, triglycerides, cholesterol and creatinine.
\end{abstract}

Conclusion: It can be concluded that the best growth performance and economical feed efficiency was observed in rabbits fed on a diet containing 30\% KFW and surpassing all treated groups and achieved the best body weight gain.

Keywords: Rabbits, Kitchen food wastes, Performance, Digestibility, Caecal, Carcass and blood parameters

\section{Background}

Livestock production in many developing countries is constrained because of poor quality and the short supply source of animal feeds (International Atomic Energy Agency, IAEA 2011). In livestock production systems, the cost of animal feed represents about $70-85 \%$ of the total recurring cost (FEFAC 2015), therefore, it is necessary to find low cost feeds incorporated in the rations of animals and poultry. Therefore, Kim (1995), Kim et al. (2001) and Yang et al. (2001) demonstrated that dried leftover

\footnotetext{
*Correspondence: soadelnaggar75@gmail.com

${ }^{1}$ Animal Production Department, National Research Centre, Dokki,

Giza 12622, Egypt

Full list of author information is available at the end of the article
}

feed could be used as feed ingredient or supplement for poultry and swine, not only to reduce the use of shortage and expensive feed ingredients, but also to decrease the environmental pollution. Food wastes may save the cost of feeding by substituting 25\% (Sehgal and Simmi 1993). It is important to put in our mind selection and handling of unconventional feed sources, that some studies reported the nutritional efficiency of leftover food which can be superior or comparable to traditional feedstuffs (Kawashima 2002). The chemical composition of food wastes is $21-29 \% \mathrm{CP}, 11-15 \% \mathrm{EE}, 2-4 \% \mathrm{CF}$ and $6-12 \%$ ash as DM basis (Kim 1995). Gustavsson et al. (2011) reported that about $30-50 \%$ of food waste discarded and considered uneaten for humans (Dou et al. 2016) especially from hotels, hospitals, restaurants and homes. 
Meanwhile, Truong et al. (2019) and Luciano et al. (2020) suggested that food wastes could be used successfully for monogastric animals and must mitigate the environmental pollution by utilized food wastes through recycling, and used it in animal feeding which reduce the cost of livestock production.

\section{Methods}

The current study was carried out at the Experimental Farm Station of the by-product Utilization Department, Animal production Institute, Agriculture Research Center, Nubaria Area and Animal Production Department, National Research Center, Dokki, Giza.

\section{Experimental rabbits and housing}

Fifty males growing New Zealand White rabbits (NZW) aged 6 weeks old with an average body weight of $650.5 \pm 3.61 \mathrm{~g}$ were blocked by weight into five equal groups (10 animals each) in a growth trial lasted 70 days. Growing NZW rabbits were obtained from a commercial farm (Agri-Feed farm, Buheira governorate, Egypt). All the experimental rabbits were healthy and clinically free from parasites and were kept under the same hygienic conditions. Experimental rabbits were housed individually in galvanized metal wire cages equipped with feeding and water troughs. Clean drinking water was freely available at all times.

\section{Diets and feeding}

The experimental diets were formed in a pelleted form to cover nutrient requirements of the breeding phase of rabbits according to NRC (1994) recommendations. Composition and chemical analysis of the feed ingredients and tested pelleted diets are shown in Table 1 . The first group of rabbits was fed control diet, while 2nd, 3rd, 4th and 5th groups were fed basal diet replacement with 10, 20, 30 and 40\% kitchen food wastes (KFW) respectively, so that the chemical composition of all diets is almost same. Experimental diets were offered daily at 8.30 a.m. Feed refusals were daily collected, weekly weighed and recorded.

\section{Collection processing of kitchen food wastes}

Kitchen food wastes were collected from houses and some small restaurants, and then it was minced and dried by solar cells in National Research Centre Labs. And analyzed for its chemical composition and essential amino acid profile is shown in Table 2.

\section{Digestibility trials}

At the end of the feeding trial, five digestibility trials were carried out over a period of seven days; where three days were for adaptation and the other four days
Table 1 Composition and chemical analysis of experiment diets

\begin{tabular}{|c|c|c|c|c|c|}
\hline & \multirow[t]{2}{*}{ Control } & \multicolumn{4}{|c|}{ kitchen food wastes } \\
\hline & & $10 \%$ & $20 \%$ & $30 \%$ & $40 \%$ \\
\hline \multicolumn{6}{|l|}{ Ingredients (\%) } \\
\hline Alfalfa hay & 30.0 & 30.0 & 30.00 & 30.00 & 30.0 \\
\hline Barley grain & 22.5 & 22.5 & 19.0 & 12.5 & 6.50 \\
\hline Soybean meal (44\%) & 20.5 & 17.0 & 13.5 & 10.0 & 6.00 \\
\hline Yellow corn & 11.5 & 6.50 & 5.00 & 5.00 & 5.00 \\
\hline Wheat bran & 8.00 & 6.5 & 5.00 & 5.00 & 5.00 \\
\hline KFW & 0.00 & 10.0 & 20.0 & 30.0 & 40.0 \\
\hline Molasses & 4.50 & 4.5 & 4.50 & 4.50 & 4.50 \\
\hline Calcium carbonate & 1.35 & 1.35 & 1.35 & 1.35 & 1.35 \\
\hline Calcium di-phosphate & 0.65 & 0.65 & 0.65 & 0.65 & 0.65 \\
\hline Sodium chloride & 0.50 & 0.50 & 0.50 & 0.50 & 0.50 \\
\hline DL-methionine & 0.10 & 0.10 & 0.10 & 0.10 & 0.10 \\
\hline Premix* & 0.40 & 0.40 & 0.40 & 0.40 & 0.40 \\
\hline \multicolumn{6}{|c|}{ Chemical analysis as dry matter basis (\%) } \\
\hline DM & 89.83 & 89.22 & 89.63 & 89.81 & 89.74 \\
\hline $\mathrm{OM}$ & 93.04 & 92.84 & 92.76 & 92.70 & 92.56 \\
\hline$C P$ & 16.97 & 17.02 & 17.11 & 17.07 & 16.99 \\
\hline CF & 13.96 & 12.98 & 12.89 & 13.03 & 13.11 \\
\hline $\mathrm{EE}$ & 2.43 & 02.85 & 03.07 & 03.22 & 03.47 \\
\hline NFE & 59.68 & 59.99 & 59.69 & 59.38 & 58.99 \\
\hline Ash & 6.96 & 07.16 & 07.24 & 07.30 & 07.44 \\
\hline NDF & 37.87 & 37.22 & 36.99 & 36.89 & 36.12 \\
\hline ADF & 19.43 & 19.37 & 19.11 & 19.09 & 19.02 \\
\hline $\mathrm{ADL}$ & 4.98 & 05.11 & 05.14 & 05.19 & 05.23 \\
\hline
\end{tabular}

*Vitamins and mineral premix at $0.4 \%$ of diet supplies the follpwing per $\mathrm{kg}$. of diet: vit. A $1200 \mathrm{IU} ; 500,000 \mathrm{IU}, \mathrm{T3} ; 0.67 \mathrm{mg}$ vit. K3; $0.67 \mathrm{mg}$ vit. B1; $2.0 \mathrm{mg} \mathrm{B2}$; 0.67 , h/vit B6; $0.004 \mathrm{mg}$. vit B12; $16.7 \mathrm{mg}$. Folic acid; $400 \mathrm{mg}$. choline chloride; $22.3 \mathrm{mg}$. Zn; $10 \mathrm{mg} \mathrm{Mn} ; 25 \mathrm{mg} \mathrm{Fe} 1.67 \mathrm{mg}$. cu' $0.25 \mathrm{mg} \mathrm{l;} 0.033 \mathrm{mg}$. Se and $133.4 \mathrm{mg} . \mathrm{Mg}$

Table 2 chemical analysis and essential amino acids of kitchen food wastes (KFW)

\begin{tabular}{llll}
\hline Essential amino acids (g/100 g sample) & \multicolumn{2}{l}{$\begin{array}{l}\text { Chemical analysis } \\
\text { (\%) }\end{array}$} \\
\hline Arginine & 1.80 & $\mathrm{DM}$ & 92.2 \\
Leucine & 1.35 & $\mathrm{OM}$ & 87.0 \\
Valine & 0.77 & $\mathrm{CP}$ & 25.1 \\
Histidine & 0.68 & $\mathrm{EE}$ & 15.3 \\
Lysine & 1.07 & $\mathrm{CF}$ & 10.3 \\
Threonine & 0.37 & $\mathrm{Ash}$ & 15.2 \\
Phenylalanine & 1.03 & $\mathrm{NFE}$ & 36.3 \\
\hline
\end{tabular}

*Value of the previous samples are the average of three samples of three batches on the dry-matter bases

for quantitative collection of feces and urine. Three random rabbits from each group were individually confined in stainless-steel metabolic cages, where feces and urine 
could separately be collected. Daily amounts of feed intake, faces and urine out-put were determined and daily recorded during the collection period.

\section{Slaughter technique and caecum parameters}

After termination of the feeding trial, three representative rabbits randomly chosen from each group were fasted for $12 \mathrm{~h}$, weighed and hand slaughtered animals were de-skinned, dressed out and the hot carcass without head was weighed and recorded. Edible offals (liver, Heart, Spleen and kidneys) were separately weighed and recorded. The whole carcass of each rabbit was de-boned and the meat of each rabbit was minced and oven dried for $72 \mathrm{~h}$ weighed to determine body water content and the dry meat was finally ground to determine protein, fat and ash.

Gastrointestinal tracts were individually removed from three slaughtered rabbits from each experimental groups, the caecal content was measured to the $\mathrm{pH}$ by using digital $\mathrm{pH}$ meter. Another sample of caecal content was filtered through four folds of faux leather for determine total and molar percentages of ammonia nitrogen and volatile fatty acids.

\section{Blood samples}

Blood samples were collected from the three slaughtered rabbits in heparinized tubes. Plasma samples were obtained by centrifugation of samples at 4000 r.p.m for $20 \mathrm{~min}$ and stored at $-20^{\circ} \mathrm{C}$ for later assay. Total plasma protein, albumin, globulin, glucose, total lipids, total cholesterol, triglycerides, HDL, LDL, urea, creatinine, AST and ALT were determined using colorimetric methods (Biodiagnostec, Egypt).

\section{Chemical analysis}

Chemical composition of feeds, KFW, feces and rabbit's meat including dry matter (DM), crude protein $(\mathrm{CP})$, crude fiber $(\mathrm{CF})$, ether extract (EE), ash, neutral detergent fiber (NDF) and acid detergent fiber (ADF) were estimated according to the methods of Association of Official Analytical Chemists (AOAC 2005). Nitrogen free extract (NFE) and acid detergent lignin (ADL) were calculated by difference. And essential amino acids according to method described by Spackman et al. (1958). Urinary nitrogen (UN) was determined by the microkjeldahl method. Concentration of ammonia nitrogen was determined calorimetrically according to Searle (1984). Total volatile fatty acids (TVFA's) and its fraction content was determined using a gas chromatograph (GC2010, Shimadzu, Kyoto, Japan) equipped with a flame Ionization detector and a capillary column (HP-INNOWAX, 1919N-133, Agilent Technologies, Santa Calra, CA, USA), as described by Hu et al. (2005).

\section{Statistical analysis}

Raw data were subjected to statistical analysis as one-way analysis of variance according to SAS (2002). The model used to analyze the different treatments studied for rabbits was as follows:

$$
Y_{i j}=\mu+T_{i}+e_{i j}
$$

where $Y_{i j}=$ observation, $\mu=$ Overall mean; $T_{i}=$ Effect of $i$ th treatments and $e_{i j}=$ Experimental error. Duncan's Multiple range test was used to detect differences between means of the experimental groups (Duncan 1955).

\section{Results \\ Chemical analysis}

Data of chemical composition of dried kitchen food wastes (KFW) and its essential amino acids profile, as well as the tested diets which containing different levels of KFW are presented in Tables 1 and 2. It is clear from results that dried KFW are rich in both CP and EE beside its valuable content of essential amino acids which considered a good feedstuff in animal feeding.

\section{Growth performance}

Growth performance evaluation of the rabbits fed varying levels of kitchen food waste during the whole experimental period are presented in Table 3 which indicated that there was no significant difference in initial body weight among groups, however rabbits receiving 40\% (FKW) substitution recorded the lowest final body weight and daily weight gain $(P<0.05)$. There were insignificant differences among the testing groups (control, 10 and $20 \%$ substitution) for both final body weight and daily weight gain, whereas the highest daily weight gain $(P<0.05)$ recorded with rabbits fed $30 \%$ KFW.

Concerning daily feed intake, the addition of (KFW) to rabbits diets had no significant differences among the experimental groups.

According to data of feed conversion ratio (g. feed/g. gain) of group five which receiving $40 \% \mathrm{KFW}$ recorded the lowest value $(P<0.05)$ compared to the other groups, whereas no significant differences among the other groups. There was a tendency that increasing KFW in the diet of growing rabbits decreased feed conversion until $30 \%$ substitution.

\section{Digestibility and nutritive values}

Nutrients digestion, nutritive value and nitrogen utilization of rabbits fed experimental diets were presented in Table 4. Rabbits who received diet of $40 \%$ (KFW) recorded the lowest $\mathrm{DM}, \mathrm{OM}, \mathrm{CP}$ and $\mathrm{CF}$ digestibility $(P<0.05)$ compared to those fed the other tested diets and there were no significant differences in DM and CF 
Table 3 Effect of dietary containing kitchen food wastes (KFW) on growth performance of growing rabbits

\begin{tabular}{|c|c|c|c|c|c|c|c|}
\hline \multirow[t]{2}{*}{ Items } & \multirow[t]{2}{*}{ Control } & \multicolumn{4}{|l|}{ KFW } & \multirow[t]{2}{*}{ SEM } & \multirow[t]{2}{*}{$P$ value } \\
\hline & & $10 \%$ & $20 \%$ & $30 \%$ & $40 \%$ & & \\
\hline IBW (g) & 646.89 & 650.33 & 646.89 & 654.11 & 647.22 & 10.66 & 0.649 \\
\hline FBW (g) & $1811.41^{b}$ & $1835.00^{b}$ & $1847.22^{b}$ & $1920.00^{b}$ & $1631.88^{c}$ & 24.84 & 0.018 \\
\hline DWG (g) & $20.79^{b}$ & $21.15^{b}$ & $21.43^{b}$ & $22.61^{\mathrm{a}}$ & $17.58^{c}$ & 0.29 & 0.037 \\
\hline DFI (g) & 91.67 & 92.33 & 92.78 & 93.17 & 89.76 & 0.37 & 0.641 \\
\hline $\begin{array}{l}\text { Feed conversion ratio (g. } \\
\text { feed/g. gain) }\end{array}$ & $4.41^{b}$ & $4.37^{b}$ & $4.33^{b}$ & $4.12^{b}$ & $5.11^{\mathrm{a}}$ & 0.15 & 0.009 \\
\hline
\end{tabular}

a,b,c Means with different superscripts in the same row differ significantly $(P<0.05)$

Table 4 Effect of feeding different levels of kitchen food wastes (KFW) on nutrients digestibility and nutritive values of diets by rabbits

\begin{tabular}{|c|c|c|c|c|c|c|c|}
\hline \multirow[t]{2}{*}{ Items } & \multirow[t]{2}{*}{ Control } & \multicolumn{4}{|l|}{ KFW } & \multirow[t]{2}{*}{ SEM } & \multirow[t]{2}{*}{$P$ value } \\
\hline & & $10 \%$ & $20 \%$ & $30 \%$ & $40 \%$ & & \\
\hline \multicolumn{8}{|c|}{ Digestibility coefficient (\%) } \\
\hline DM & $63.63^{\mathrm{a}}$ & $63.40^{\mathrm{a}}$ & $63.56^{\mathrm{a}}$ & $65.46^{\mathrm{a}}$ & $60.16^{b}$ & 0.07 & 0.016 \\
\hline $\mathrm{OM}$ & $64.43^{\mathrm{a}}$ & $63.72^{b}$ & $63.88^{b}$ & $64.08^{\mathrm{a}}$ & $61.11^{c}$ & 0.07 & 0.011 \\
\hline $\mathrm{CP}$ & $58.79^{c}$ & $62.30^{b}$ & $62.46^{\mathrm{a}}$ & $64.29^{a}$ & $55.54^{d}$ & 0.05 & 0.001 \\
\hline CF & $44.78^{\mathrm{a}}$ & $45.75^{\mathrm{a}}$ & $45.67^{\mathrm{a}}$ & $45.66^{\mathrm{a}}$ & $40.58^{b}$ & 0.37 & 0.048 \\
\hline $\mathrm{EE}$ & $68.72^{c}$ & $71.33^{b}$ & $75.43^{b}$ & $75.37^{\mathrm{a}}$ & $70.55^{b c}$ & 0.29 & 0.039 \\
\hline NFE & $70.32^{\mathrm{a}}$ & $67.65^{b}$ & $67.62^{b}$ & $67.46^{b}$ & $66.72^{b}$ & 0.43 & 0.044 \\
\hline \multicolumn{8}{|c|}{ Nutritive values } \\
\hline TDN & $61.30^{c}$ & $61.63^{c}$ & $62.15^{b}$ & $64.29^{\mathrm{a}}$ & $59.28^{\mathrm{a}}$ & 0.14 & 0.035 \\
\hline DCP & $9.98^{b}$ & $10.60^{\mathrm{a}}$ & $10.69^{a}$ & $10.97^{\mathrm{a}}$ & $09.44^{c}$ & 0.04 & 0.017 \\
\hline \multicolumn{8}{|c|}{ Nitrogen utilization } \\
\hline $\mathrm{NI}$ & 2.49 & 2.51 & 2.54 & 2.54 & 2.44 & 0.44 & 0.533 \\
\hline NB & $1.03^{b}$ & $1.15^{\mathrm{b}}$ & $1.18^{b}$ & $1.25^{\mathrm{a}}$ & $0.79^{c}$ & 0.08 & 0.012 \\
\hline $\mathrm{NB} / \mathrm{NI}$ & $41.37^{b}$ & $45.82^{a}$ & $46.46^{a}$ & $49.21^{a}$ & $32.38^{c}$ & 0.54 & 0.033 \\
\hline
\end{tabular}

a,b,c Means with different superscripts in the same row differ significantly $(P<0.05)$

digestibility among the other groups, while rabbits fed a diet containing 30\% (KFW) substitution showed the highest $\mathrm{OM}, \mathrm{CP}$ and EE digestibility $(P<0.05)$ compared with the other groups.

Meantime, insignificant differences were observed in CF digestibility among control, $10 \%$ and $20 \%$ KFW substitution, also there was no significant difference in $\mathrm{CP}$ digestibility between rabbits receiving diets containing $10 \%$ and $20 \%(\mathrm{KFW})$ but they were significantly $(P<0.05)$ higher compared with the control group.

The highest EE digestibility $(P<0.05)$ was recorded with $20 \%$ and $30 \%$ KFW substitution and the lowest EE value $(P<0.05)$ showed with the control group. In addition, rabbits fed control diet recorded the highest NFE digestibility compared with other groups which recorded no significant differences among them.

The lowest nutritive values as TDN and DCP recorded with the $40 \% \mathrm{KFW}$, while the $30 \% \mathrm{KFW}$ recorded the best TDN $(P<0.05)$, followed by $20 \%$ then the control and $10 \% \mathrm{KFW}$. DCP values were significantly higher $(P<0.05)$ for 10,20 and $30 \%$ of substitution comparing with the other two tested groups (Table 4). Rabbits fed diets of $40 \% \mathrm{KFW}$ recorded the lowest nitrogen utilization $(P<0.05)$ as nitrogen intake $(\mathrm{NI})$, nitrogen balance $(\mathrm{NB})$ and NB/NI, meantime there was no significant difference in NI among all groups.

\section{Caecal liquor parameter}

Data in Table 5 elucidated that there was no significant difference in caecal $\mathrm{pH}$ values among all tested groups. Rabbits fed $0,10,20$ and $30 \%$ of KFW substitution showed significant low values $(P<0.05)$ of caecal ammonia nitrogen $\left(\mathrm{NH}_{3}-\mathrm{N}\right) \mathrm{mmol} / 1$ comparing with $40 \%$ of FKW diet. On the other hand, volatile fatty acids (VFA's) values were significantly higher $(P<0.05)$ with rabbits groups fed control, 10, 20 and 30\% KFW substitution compared with $40 \%$ substitution group which recorded the lowest estimate. 
Table 5 Effect of dietary containing kitchen food wastes (KFW) on caecal $\mathrm{pH}$, ammonia nitrogen $\left(\mathrm{NH}_{3}-\mathrm{N}\right)$ and volatile fatty acids (VFA's) of growing rabbits

\begin{tabular}{|c|c|c|c|c|c|c|c|}
\hline \multirow[t]{2}{*}{ Items } & \multirow[t]{2}{*}{ Control } & \multicolumn{4}{|l|}{ KFW } & \multirow[t]{2}{*}{ SEM } & \multirow[t]{2}{*}{$P$ value } \\
\hline & & $10 \%$ & $20 \%$ & $30 \%$ & $40 \%$ & & \\
\hline $\mathrm{pH}$ & 6.25 & 6.24 & 6.31 & 6.33 & 6.39 & 0.28 & 0.663 \\
\hline $\mathrm{NH}_{3}-\mathrm{N}_{3}(\mathrm{mmol} / \mathrm{l})$ & $5.45^{b}$ & $5.58^{b}$ & $5.69^{b}$ & $5.81^{\mathrm{ab}}$ & $5.97^{\mathrm{a}}$ & 0.13 & 0.032 \\
\hline TVFA's (mmol/l) & $62.87^{\mathrm{a}}$ & $62.83^{\mathrm{a}}$ & $62.89 a$ & $63.07^{\mathrm{a}}$ & $61.22^{\mathrm{b}}$ & 0.47 & 0.001 \\
\hline \multicolumn{8}{|c|}{ VFA's percentage (\%) } \\
\hline Acetate & $74.85^{b}$ & $74.63^{b}$ & $74.49^{b}$ & $74.33^{\mathrm{b}}$ & $76.94^{\mathrm{a}}$ & 0.87 & 0.016 \\
\hline Propionate & $08.56^{b}$ & $08.81^{\mathrm{a}}$ & $08.95^{\mathrm{a}}$ & $09.37^{\mathrm{a}}$ & $06.88^{c}$ & 0.22 & 0.037 \\
\hline Butyrate & 14.07 & 14.22 & 14.31 & 14.52 & 14.96 & 0.87 & 0.672 \\
\hline
\end{tabular}

$a, b, c$ Mean in the same row bearing different superscripts are significantly different

As for VFA's fractionation, the highest acetate \% was recorded with the $40 \%$ KFW substitution comparing with other experimental groups, while propionate $\%$ was significantly high $(P<0.05)$ for groups 10,20 and $30 \%$ (KFW) substitution followed by the control group, whereas, the lowest percentage of propionate recorded with $40 \%$ substitution. In addition, there was no significant difference $(P<0.05)$ with butyrate molar fraction among all groups.

\section{Carcass characteristics}

The effect of KFW inclusion on the carcass characteristics of the experimentation rabbits are shown in Table 6. The obtained data revealed that the pre-slaughter weight was an insignificant difference among all groups, while hot carcass weight was nearly similar among the tested groups, hence the highest hot carcass weight $(P<0.05)$ was recorded for 30 and $40 \%$ KFW substitution compared with control group and without significant difference between groups of 10 and $20 \%$ substitution.

Dressing percentage was significantly high $(P<0.05)$ for 40\% KFW substitution and without significant difference with groups of 20 and 30\% KFW followed by $10 \%$ KFW, the lowest dressing percentage $(P<0.05)$ was recorded for the control group. And there was no significant effect for liver and heart among the tested groups. Meanwhile, kidney and lung recorded the highest weight $(P<0.05)$ for control compared with $40 \%$ of KFW, while the other levels recorded moderate weights.

Chemical composition of rabbit's meat was shown in Table 7 and represents that moisture and CP \% of meat were nearly similar among all tested groups except the $30 \%$ substitution, which recorded the highest percentages $(P<0.05)$. As for EE \% of meat was $(P<0.05)$ high for $20 \%$ KFW followed by the other experimental groups which showed similar results, however ash percentages were varied among groups hence it was significantly $(P<0.05)$ high for control and the lowest ash \% $(P<0.05)$ was recorded for the meat of $40 \% \mathrm{KFW}$ substitution.

\section{Blood biochemical parameters}

Plasma biochemical values demonstrated some significant differences $(P<0.05)$ among the experimental groups by adding different levels of KFW in rabbit's diets (Table 8). The concentration of total plasma protein (g/ dl) was significantly high $(P<0.05)$ for KFW of 20 and

Table 6 Effect of diet containing different levels of kitchen food wastes (KFW) on carcass characteristics of growing rabbits

\begin{tabular}{|c|c|c|c|c|c|c|c|}
\hline \multirow[t]{2}{*}{ Items } & \multirow[t]{2}{*}{ Control } & \multicolumn{4}{|c|}{ Kitchen food wastes (KFW) } & \multirow[t]{2}{*}{ SEM } & \multirow[t]{2}{*}{$P$ value } \\
\hline & & $10 \%$ & $20 \%$ & $30 \%$ & $40 \%$ & & \\
\hline Pre slaughter weight (g) & 1761 & 1786 & 1743 & 1872 & 1562 & 8.60 & 0.644 \\
\hline Hot carcass weight (g) & $851.00^{b}$ & $887.00^{a b}$ & $896.20^{a b}$ & $909.20^{\mathrm{a}}$ & $914.00^{\mathrm{a}}$ & 7.55 & 0.049 \\
\hline Dressing \% & $54.53^{c}$ & $55.93^{b c}$ & $58.07^{a b}$ & $57.85^{\mathrm{ab}}$ & $58.53^{\mathrm{a}}$ & 0.42 & 0.003 \\
\hline Liver (g) & 53.82 & 54.96 & 50.98 & 58.36 & 49.69 & 1.25 & 0.845 \\
\hline Kidney (g) & $14.24^{\mathrm{a}}$ & $13.31^{a b}$ & $13.02^{b}$ & $14.10^{\mathrm{a}}$ & $10.82^{c}$ & 0.19 & 0.028 \\
\hline Spleen (g) & $1.03^{\mathrm{a}}$ & $0.99^{\mathrm{ab}}$ & $0.88^{b}$ & $1.20^{\mathrm{a}}$ & $1.02^{\mathrm{a}}$ & 0.03 & 0.062 \\
\hline Heart (g) & 5.43 & 5.38 & 4.86 & 5.63 & 4.77 & 0.20 & 0.934 \\
\hline
\end{tabular}

a,b,c Means with different superscripts in the same row differ significantly $(P<0.05)$ 
Table 7 Chemical composition of rabbit's meat (on fresh basis) fed experimental rations

\begin{tabular}{|c|c|c|c|c|c|c|c|}
\hline \multirow[t]{2}{*}{ Items } & \multirow[t]{2}{*}{ Control } & \multicolumn{4}{|l|}{ KFW } & \multirow[t]{2}{*}{ SEM } & \multirow[t]{2}{*}{$P$ value } \\
\hline & & $10 \%$ & $20 \%$ & $30 \%$ & $40 \%$ & & \\
\hline Moisture (\%) & $68.82^{\mathrm{ab}}$ & $68.62^{a b}$ & $68.44^{\mathrm{ab}}$ & $69.04^{\mathrm{a}}$ & $68.35^{b}$ & 0.10 & 0.172 \\
\hline CP (\%) & $19.70^{b}$ & $19.56^{\mathrm{b}}$ & $19.53^{b}$ & $20.18^{\mathrm{a}}$ & $19.97^{\mathrm{ab}}$ & 0.09 & 0.036 \\
\hline EE (\%) & $4.73^{b}$ & $4.81^{\mathrm{ab}}$ & $4.95^{\mathrm{a}}$ & $4.69^{b}$ & $4.68^{b}$ & 0.03 & 0.024 \\
\hline Ash (\%) & $1.78^{\mathrm{a}}$ & $1.63^{\mathrm{b}}$ & $1.34^{c}$ & $1.12^{d}$ & $1.05^{d}$ & 0.08 & 0.000 \\
\hline Others (\%) & 3.97 & 4.38 & 4.73 & 3.96 & 4.95 & 0.16 & 0.1422 \\
\hline
\end{tabular}

$a, b, c$ Means with different superscripts in the same row differ significantly $(P<0.05)$

Table 8 Effect of dietary containing different kitchen food wastes levels on some blood biochemical parameters of growing rabbits

\begin{tabular}{|c|c|c|c|c|c|c|c|}
\hline \multirow[t]{2}{*}{ Items } & \multirow[t]{2}{*}{ Control } & \multicolumn{4}{|l|}{ KFW } & \multirow[t]{2}{*}{ SEM } & \multirow[t]{2}{*}{$P$ value } \\
\hline & & $10 \%$ & $20 \%$ & $30 \%$ & $40 \%$ & & \\
\hline Total protein (g/dl) & $06.37^{b}$ & $06.68^{b}$ & $06.71^{a}$ & $06.88^{a}$ & $06.16^{c}$ & 0.27 & 0.021 \\
\hline Albumin (g/dl) & $03.27^{\mathrm{a}}$ & $3.33^{\mathrm{a}}$ & $03.39^{a}$ & $03.79^{a}$ & $02.93^{b}$ & 0.11 & 0.014 \\
\hline Globulin (g/dl) & 03.10 & 03.35 & 03.32 & 03.39 & $03.23^{c}$ & 0.42 & 0.642 \\
\hline Glucose (mg/dl) & 81.34 & 81.28 & 81.41 & 81.49 & $80.52^{a}$ & 0.73 & 0.591 \\
\hline Total lipids (g/l) & $03.05^{c}$ & $03.23^{b c}$ & $03.52^{b}$ & $03.89^{a}$ & $04.52^{\mathrm{a}}$ & 0.33 & 0.001 \\
\hline Cholesterol (mg/dl) & $189.66^{c}$ & $204.24^{b c}$ & $221.31^{b}$ & $239.55^{b}$ & $284.62^{\mathrm{a}}$ & 16.63 & 0.001 \\
\hline Triglycerides (mg/dl) & $67.45^{c}$ & $69.33^{b c}$ & $70.17^{b}$ & $72.66^{b}$ & $75.33^{a}$ & 1.79 & 0.001 \\
\hline $\mathrm{HDL}(\mathrm{mg} / \mathrm{dl})$ & 32.63 & 32.68 & 32.73 & 32.98 & 33.02 & 0.51 & 0.522 \\
\hline $\mathrm{LDL}(\mathrm{mg} / \mathrm{dl})$ & $81.43^{b}$ & $82.14^{b}$ & $82.69^{b}$ & 82.93 & $84.08^{a}$ & 0.27 & 0.31 \\
\hline Urea (mg/dl) & $35.53^{b}$ & $35.89^{a b}$ & 36.15 & 36.31 & $37.33^{\mathrm{a}}$ & 0.16 & 0.007 \\
\hline Creatinine (mg/dl) & $00.76^{c}$ & $00.81^{b}$ & $00.82^{b}$ & 00.88 & $00.96^{\mathrm{a}}$ & 0.06 & 0.002 \\
\hline AST (U/L) & 31.77 & 32.53 & 31.94 & 32.07 & 31.35 & 0.62 & 0.662 \\
\hline $\mathrm{ALT}(\mathrm{U} / \mathrm{L})$ & 15.74 & 15.87 & 15.66 & 15.69 & 15.47 & 0.59 & 0.721 \\
\hline
\end{tabular}

$\mathrm{a}, \mathrm{b}, \mathrm{c}$ Mean in the same row bearing different superscripts are significantly different

$30 \%$ substitution followed by zero and $10 \%$ of KFW, whereas the lowest concentration $(P<0.05)$ was recorded with $40 \% \mathrm{KFW}$. Plasma albumin $(\mathrm{g} / \mathrm{dl})$ was significantly low $(P<0.05)$ with $40 \%$ level of KFW compared with the other groups which showed insignificant difference.

Moreover, there were no significant differences in plasma globulin, glucose, HDL, AST and ALT among all the experimental groups. Total plasma lipids concentration was significant $(P<0.05)$ high with groups 30 and $40 \% \mathrm{KFW}$ followed by groups of 10 and $20 \% \mathrm{KFW}$, while the lowest concentration $(P<0.05)$ was for the control group. Concerning plasma cholesterol and triglycerides content revealed that, addition of kitchen food wastes to rabbit's diets had different significant effects, which recorded the highest values with $40 \%$ group, while the lowest concentrations $(P<0.05)$ were recorded for control followed by groups 10, 20 and $30 \% \mathrm{KFW}$, but without any significant difference between zero and $10 \%$ of KFW.

Also, there was significant increase $(P<0.05)$ in plasma LDL level with $40 \% \mathrm{KFW}$, but there were no significant differences among the other groups. Plasma urea concentration was significantly low $(P<0.05)$ for groups zero and $10 \% \mathrm{KFW}$, while the other three tested groups recorded $(P<0.05)$ high significant values. The concentration of plasma creatinine was significantly $(P<0.05)$ high for groups of 30 and $40 \%$ of KFW substitution, while the lowest content recorded by the control group.

\section{Discussion}

Data of Table 2 showed that the value of $\mathrm{CP}$ is comparable to the range recorded by Kim (1995) and Cho et al. (2004).

The results of Table 3 agree with Westendorf et al. (1998) who reported that weight gains of pigs fed 50\% of cafeteria food waste (CFW) substitution from soybean meal were not different compared with $0 \%$ CFW diet. Also, there were insignificant differences in daily weight gain among steers fed substitution level of dried leftover food (DLF) 0, 25, 50, 75\% of diet (Paek et al. 2005). Meanwhile, Farhat et al. (2001) and Enasa et al. (2018) reported improvements in body weight gain of ducks fed diets containing 30\% DLF. In addition, 
increased level of kitchen food wastes to $40 \%$ substitution in the diet decreases daily weight gain because of low nutritive value of KFW, particularly in TDN and DCP values.

Daily DM intake was comparable among groups, these results are in agreement with McClure et al. (1970) who demonstrated that daily feed intake of sheep and beef cattle fed DLF was similar to those fed control feed and with Summers et al. (1980) who indicated that sheep fed 30\% DLF substitution of diet has similar feed intake with control group. Also, daily dry matter intake in this study was insignificant increase up to $30 \%$ KFW substitution, these results agree with Maeng et al. (1997) and Amene et al. (2016) who recorded increasing feed intake of hens fed DLF, and with Pigs fed dried cafeteria leftover (DCL) respectively.

Data of Table 4 showed that rabbits fed diet containing 30\% KFW substitution showed the highest OM, CP and EE digestibility $(P<0.05)$ compared with the other groups, and those agreed with Chae et al. (2000) who reported that $\mathrm{CP}$ and $\mathrm{EE}$ digestibility were increased with increasing levels of dried food waste in the diets of pigs. The high CP content of KFW may be enhancing the efficiency of rumen microflora such as proteolytic bacteria and cellulytic bacteria which leads to increase nutrients digestibility (Dawson et al. 1990). Also, Kil et al. (1999) recorded that incorporating DLF in ruminant diets increased the generation of rumen ammonia which increase the absorption of nitrogen through stomach walls. Meanwhile, pigs fed diets consisted of DCL showed higher DM digestibility (Almeida et al. 2014) and higher CF and EE digestibility (Amene et al. 2016), may be due to the existence of soluble components in DCL or exposed food to heat treatment during cooking which increase food digestibility.

As shown in Table 5 there were insignificant differences observed in $\mathrm{pH}$ of caecal contents and slightly like obtained with Garcia et al. (2002) ( $\mathrm{pH}$ 5.4-6.8). The caecal TVFA's concentration increased with diets containing KFW could be due to high digestible DM (Allam et al. 1984), high digestible OM (El-Ashry et al. 2003) and high digestible CF of KFW resulted from the activity of microbial population (Doane et al. 1997), which could be well utilized by rabbits since they have hind gut fermentation. Besides, fermentation process which is performed by microflora enables rabbits to obtain protein and energy from feed with moderate fiber materials.

Data of Table 6 of dressing \% agree with Cho et al. (2004) who revealed that increasing the level of DLF in the diet affected significantly on dressing percentage and carcass weight of hens. And were not in agreement with that reported by Chen et al. (2007) and Mousa et al.
(2018) who found that duck's diets contain DLF had no significant effect $(P<0.05)$ on dressing $\%$, carcass weight and relative weights of liver and heart.

Table 7 represents that chemical analysis of meat were nearly similar among all tested groups which reflect that KFW has not any adverse effect on meat that it is food wastes of human and agree with found by Westendorf et al. (1998) who reported that meat quality of pigs fed CFW similar with those fed 0 CFW.

Blood parameters of Table 8 showed insignificant differences in plasma globulin, glucose, HDL, AST and ALT among all the experimental groups and this mean that inclusion of KFW in the diets had no adverse effect on rabbits health. While, Chen et al. (2007) showed higher value of serum AST with increasing dried food waste in chickens diets up to $20 \%$. However, Hassanien et al. (2020) found no significant concentrations of blood total protein, globulin, cholesterol, AST, ALT, urea and creatinine for cows fed dried leftover up to $40 \%$ of diets. Concerning plasma total cholesterol and triglycerides content, substitution of KFW of rabbit's diets recorded the highest values with $40 \%$ group, while the lowest concentrations $(P<0.05)$ were recorded for other diets. Cho et al. (2004) found that feeding dried leftover food to broilers had no significant effect on blood total cholesterol concentrations and Mousa et al. (2018) reported that triglyceride increased with increasing the level of leftover in duck diets up to $30 \%$ of diet. According to several researchers, one of the factors affecting content of cholesterol in the blood was fiber content in animal feed. Palmer and Zilversmit (1974) and Adams et al. (2018) suggested that cellulose as an indigestible material controlled the cholesterol metabolism and affected cholesterol concentration in blood and cholesterol turnover rate.

The overall conclusion form the feeding trials through several places demonstrated that kitchen food wastes are nutritionally suitable for use as animal feed, however, the recommend approach is to use it in a combined feed, in order to ensure that a nutritionally balanced feed can be safety provided (Westendorf et al. 1998).

\section{Conclusion}

Results of the current study concluded that the best growth performance, feed conversion and meat quality was observed clearly for rabbits fed diets containing 30\% of kitchen food wastes which surpassing all the tested groups.

The reasonable growth performance obtained in this study could encourage the researcher to recommend the use of kitchen food wastes at 30\% in replacement of expensive normal diet as a non-conventional cheap 


\section{feedstuff in warning rabbit's diets without any disorders effects on growth performance or hygiene.}

\begin{abstract}
Abbreviations
KFW: Kitchen food wastes; NZW: New Zealand White rabbits; g: Gram; DM: Dry matter; OM: Organic matter; CP: Crude protein; CF: Crude fiber; EE: Ether extract; NFE: Nitrogen free extract; NDF: Neutral detergent fiber; ADF: Acid detergent fiber; ADL: Acid detergent lignin; UN: Urinary nitrogen; TVFA's: Total volatile fatty acids; ALT: Alanine aminotransferase; AST: Aspartate aminotransferase; HDL: High density lipoprotein; IAEA: International Atomic Energy Agency; LDL: Low density lipoprotein; SAS: Statistical Analysis System; IBW: Initial body weight; FBW: Final body weight; DWG: Daily weight gain; DFI: Daily feed intake; TDN: Total digestible nutrients; NI: Nitrogen intake; NB: Nitrogen
\end{abstract} balance: CFW: Cafeteria food waste: DLF: Dried leftover food.

\section{Acknowledgements}

The authors would like to thank The Research Projects Office of The National Research Centre for financing this work.

\section{Authors' contributions}

Conceptualization, $\mathrm{FH}$ and $\mathrm{AE}$; Data curation, $\mathrm{SE}, \mathrm{MMB}$ and $\mathrm{EE} ;$ Investigation, $\mathrm{FH}, \mathrm{AE}$ and SE; Methodology, FH, MMB, EE and SE. Supervision, $\mathrm{FH}$ and $\mathrm{AE} ;$ Validation, FH and SE. Visualization, Writing —original draft FH, AE and SE. Writing - review and editing, AE and SE. All authors have read and agreed to the published version of the manuscript.

\section{Funding}

Project No: 10060104 from National Research Centre are the funding sources in the design of the study and collection, analysis and interpretation of data, and in writing of the manuscript.

\section{Availability of data and materials}

The datasets used and/or analyzed during the current study are available from the corresponding author on request.

\section{Declarations}

\section{Ethics approval and consent to participate}

The experimental design and all the research protocols were approved by the Medical Research Ethics Committee (MREC) of the National Research Center with ethical approval code 20/189.

\section{Consent for publication}

"Not applicable".

\section{Competing interests}

The authors declare that they have no competing interests.

\section{Author details}

${ }^{1}$ Animal Production Department, National Research Centre, Dokki, Giza 12622, Egypt. ${ }^{2}$ Department of Poultry Nutrition, Agriculture Research Centre, Dokki, Giza 12618, Egypt.

Received: 9 March 2021 Accepted: 14 April 2021

Published online: 26 April 2021

\section{References}

Allam SM, Abou Raya AK, Gehad EA and El-Bedawy TM (1984) Nutritional studies by sheep and goats fed $\mathrm{NaOH}$ treated straw. In: Egyptian British conference on animal and poultry production, Zagazig, 11-13 Sept 1984, p 53

AOAC (2005) Association of official analytical chemists. Official methods of analysis, 18th ed. Washington, DC, USA

Adams S, Sello CT, Qin G, Che D, Han R (2018) Does dietary fiber affect the levels of nutritional components after feed formulation? Fibers 6:29. https:// doi.org/10.3390/fib6020029
Almeida FN, Htoo JK, Thomson J, Stein HH (2014) Effects of heat treatment on the apparent and standardized ileal digestibility of amino acids in canola meal fed to growing pigs. Anim Feed Sci Technol 187:44-52

Amene T, Urge M, Eshetu M, Diba D (2016) Effects of different proportions of dried Cafeteria leftover inclusion in a concentrate mix on performance of growing pigs. Sci Technol Arts Res J 5(1):27-34

Chae BJ, Choi SC, Kim YG, Kim CH, Sohn KS (2000) Effects of feeding dried food waste on growth and nutrient digestibility in growing-finishing pigs. Asian Aust J Anim Sci 13:1304-1308

Chen KL, Chang HJ, Yang CK, You SH, Jenq HD, Yu B (2007) Effect of dietary inclusion of dehydrated food waste products on taiwan native chichen. Asian Aust J Anim Sci 20(5):754-760

Cho YM, Lee GW, Jang JS, Shin IS, Myung IH, Choi KS, Bai IH, Yang CJ (2004) Effects of feeding dried leftover food on gowth and body composition of boriler chicks. Asian Aust J Anim Sci 17(3):386-393

Dawson KA, Newman KE, Boling JA (1990) Effect of microbial supplements containing yeast and lactobacilli on roughage fed ruminal microbial activities.J Anim Sci 68:3392-3398

Doane PH, Schofield P, Pell AN (1997) Neutral detergent fiber disappearance and gas volatile fatty acid production during the in vitro fermentation of six forage. J Anim Sci 75:3342-3352

Dou Z, Ferguson J, Galligan D, Kelly A, Finn S, Giegengack R (2016) Assessing U.S. food wastage and opportunities for reduction. Glob Food Sect 8:19-26

Duncan DB (1955) Multiple range and multiple F. tests. Biometric 11:1

El-Ashry MA, Kholif AM, Fadel M, El-Alamy HA, El-Sayed HM, Kholif SM (2003) Effect of biological treatments on chemical composition, in vitro and in-vivo nutrients digestibilities of poor quality roughage. Egypt J Nutr Feeds 5(1):55-69

Enasa FM, Hassan AM, Gehan RM (2018) Using dried leftover foods as untraditional feed in Muscovy duck diets. Assiut Vet Med J 64(158):107-114

Farhat A, Normand L, Chavez ER, Touchburn SP (2001) Comparison of grwoth performance, carcass yield and composition, and fatty acid profiles of pekin and Muscovy ducklings fed diets based on food wastes. Can J anim Sci 81:107-114

FEFAC, The FEFAC 2030 Animal Feed Industry Vision. Annual report 20152016; European Feed Manufacturers'Federation (FEFAC): Bruxelles, Belgium, 2015; pp 1-23

Garcia J, Gidenne T, Falcaoe Cunha L, de Blas C (2002) Identification of the main factors that influence caecal fermentation traits in growing rabbits. Anim Res 51:165-173

Gustavsson J, Cederberg C, Sonesson U, van Otterdijk R, Meybeck A (2011) Global food losses and food waste. FAO, Rome

Hassanien HAM, Phillip YL, Abou El-Fadel MH, Khayyal AA, Hussein AM, Matari RIM, Elsheikh HA (2020) Utilization of leftover food collected from hotels in rations of crossbred cow calves. J Anim Poultry Prod Mansoura Univ 11(5):169-174

Hu WL, Liu JX, Ye JA, Wu YM, Guo YQ (2005) Effect of tea saponin on rumen fermentation in vitro. Anim Feed Sci Technol 120:333

International atomic energy agency, Nuclear Security Recommendations on Radioactive Material and Associated Facilities, IAEA Nuclear Security Series No. 14, IAEA, Vienna (2011)

Kawashima $T$ (2002) The use of food waste as a protein source for animal feed — current status and technological development in Japan. Paper presented at the FAO Expert Consultation and Workshop on Protein sources for the animal feed industry, Bangkok, Thailand. April 29-May 3

Kil JY, Kim HJ, Lee DH, Cho SB, Lee SR, Maeng WJ (1999) Study on degradation pattern of nutrients by food waste in the rumen. In: Proceedings of the 8th annual congress of Korean Society of Animal Science, p 183, Chuchon, Korea

Kim NC (1995) Feedstuff of food garbage by the rapid steam drying. J KOWREC Kor 3(2):69-78

Kim CH, Song YH, Chae BJ, Rhee YC (2001) Effects of feeding extruded swine manure and food waste mixture diets on growth performance, body composition and feeding behavior of broilers. J Anim Sci Technol Kor 43(1):91-100

Luciano A, Tretola M, Ottoboni M, Baldi A, Cattaneo D, Pinotti L (2020) Potentials and challenges of former food products (food leftover) as alternative feed ingredients. Animals 10:125. https://doi.org/10.3390/ ani10010125 
Maeng WJ, Chung SH, Lee SR, Kim C, Ahn JJ (1997) Effects of food wastes as a fermented feed on egg laying. In: Proceedings of the 7th annual congress of Korean Society of Animal Science, p 184

McClure KE, Klosterman EW, Johnson RR (1970) Palatability and digestibility of processed garbage fed to ruminants. J Anim Sci 31:249

Mousa EF, Abdel-Raheem HAM, Dawood GRM (2018) Using dried leftover foods as untraditional feed in Muscovy Duck diets. Assiut Vet Med J 64(158):107-114

NRC (1994) Nutrients requirements of poultry, 8th edn. National Acad. Press, Washington

Paek BH, Kang SW, Cho YM, Cho WM, Yang CJ, Yun SG (2005) Effects of substituting concentrates with dried leftover food on growth and carcass characteristics of Hanwoo steers. Asian Aust J Anim Sci 18(2):209-213

Palmer J, Zilversmit DB (1974) Effects of dietary roughage on cholesterol absorption, cholesterol turnover and steroid excretion in the rat. J Nutr 104:1319-1328

SAS (2002) Statistical analysis systems (SAS) Institute Inc., 2002. SAS/ STAT. User Searle LP (1984) The berthelot or indophenol reaction and its use in the analytical chemistry of nitrogen: a review. Analyst 109:549

Sehgal HS, Sharma S (1993) A note on evaluation of some wastes and by products from agriculture and animal husbandry feed ingredients for Cirrhina mirigala. Biores Technol 41:9-11
Spackman D, Stein W, Moore S (1958) Automatic recording apparatus for use in the chromatography of amino acids. Anal Chem 30(7):1190-1206

Summers JD, Macleod GK, Warner WC (1980) Chemical composition of culinary wastes and their potential as a feed for ruminants. Anim Feed Sci Technol 5(3):205-214

Truong L, Morash D, Liu Y, King A (2019) Food waste in animal feed with a focus on use for broilers. Int J Recycl Org Wast Agric 8(4):417-429

Westendorf ML, Dong ZC, Schoknecht PA (1998) Recycled cafeteria food waste as a feed for swine: nutrient content digestibility, growth, and meat quality. J Anim Sci 76(12):2976-2983

Yang SY, Park HY, Kim CW, Park KK (2001) Isolation of halo-tolerent lactic acid bacteria for fermentation of food wastes. J L H Kor 7(2):137-140

\section{Publisher's Note}

Springer Nature remains neutral with regard to jurisdictional claims in published maps and institutional affiliations.

\section{Submit your manuscript to a SpringerOpen ${ }^{\circ}$ journal and benefit from:}

- Convenient online submission

- Rigorous peer review

- Open access: articles freely available online

- High visibility within the field

- Retaining the copyright to your article

Submit your next manuscript at $\boldsymbol{\sim}$ springeropen.com 